\section{Plasmider og gentamicinresistens i enterokokker}

\author{
Forekomsten av gentamicinresistente enterokokker er økende. Entero- \\ kokker isolert i sykehus har flere bevegelige DNA-fragmenter som kan \\ overføre gener for bl.a. resistens.
}

Enterokokker finnes i normal tarmflora. De gir sjelden alvorlig infeksjon hos friske, men ses ofte ved sykehusinfeksjoner. Sykehustilpassede enterokokkstammer har egenskaper som gjør dem spesielt egnet til å overleve i sykehusmiljøet, bl.a. resistens mot antibiotika. Resistensgener sitter ofte på plasmider, små DNA-fragmenter som kan overføres mellom bakteriene. Torill Solvær Rosvoll har sett på forekomsten av plasmider i ulike antibiotikaresistente enterokokkisolater.

- Vi fant overraskende mange ulike plasmidtyper i enterokokkene, forteller hun. - Noen isolater hadde så mye som sju ulike plasmider. Sykehustilpassede bakterier hadde generelt flere plasmider enn andre isolater. Mange av disse plasmidene finnes i en rekke bakterietyper.

Enterokokker har en stor evne til å utveksle antibiotikaresistens seg imellom, og - mer bekymringsfullt - til andre og mer virulente bakterier, fortsetter hun.

Forekomsten av sykehustilpassede enterokokker som er resistente mot både ampicillin og gentamicin er tidoblet de siste årene. Disse bakteriene vil ikke respondere på empirisk sepsisbehandling.

- Blant de gentamicinresistente E. faeciumisolatene vi undersøkte, satt genet for gentamicinresistens på såkalte megaplasmider i $100 \%$ av isolatene, sier Rosvoll. - Megaplasmider er en virulensfaktor i seg selv. Dette er store plasmider som gir økt genutveksling og gjør at enterokokkene kan erverve egenskaper som øker virulensen ytterligere, avslutter hun.

\section{Kristin Viste}

kristin.viste@legeforeningen.no

Tidsskriftet

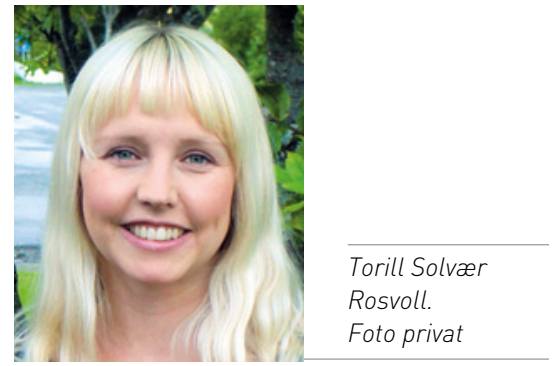

Disputas

Torill Solvær Rosvoll disputerte for ph.d.graden ved Universitetet i Tromsø 21.6. 2012. Tittelen på avhandlingen er Plasmids, resistance and hospital adaptation in Enterococci: an epidemiological approach

\title{
Fritid, sport og bruddskader hos barn
}

\section{Lek på snowboard forårsaker fire ganger flere brudd per time enn andre aktiviteter, og nær 80 \% av bruddene er håndleddsbrudd. Den vanligste typen trenger ingen oppfølging.}

Omtrent $40 \%$ av bruddskadene hos barn forårsakes av sports- og fritidsaktiviteter. For å redusere forekomsten av bruddskader hos barn trengs kunnskap om hvilke aktiviteter som gir høyest bruddrisiko. Dette er et av temaene i Per-Henrik Randsborgs avhandling.

- I Barnebruddregisteret ved Akershus universitetssykehus har man registrert alle brudd hos barn i vårt distrikt i 2010 og 2011. Totalt ble 1403 brudd inkludert. Vi noterte hvilke aktiviteter som var årsaken til bruddskaden og hvor mange timer barna brukte på de ulike aktivitetene. Våre data viste at lek på snowboard ga fire ganger flere brudd per time enn andre aktiviteter. Nær $80 \%$ av bruddene var håndleddsbrudd - og barna brukte ikke håndleddsbeskyttere. Håndballspilling var mer risikabelt enn hopping på trampoline - det ga dobbelt så mange brudd per time, sier Randsborg.

Randsborg så nærmere på resultatene av behandling av håndleddsbrudd - som utgjør mer enn $30 \%$ av bruddskadene hos barn.

- Vanligst hos barn er helt stabile håndleddsbrudd - det trengs ingen oppfølging. Behandlingen kan bestå i å legge på en støttebandasje, som foreldrene kan fjerne etter tre uker. Mer vekt på klassifisering av håndleddsbrudd kan redusere antall unødvendige kliniske og radiologiske kontroller og spare betydelige ressurser, sier han.

- Det er behov for mer detaljerte studier av aktiviteter som gir høy risiko for bruddskader, som det å stå på snowboard eller å spille håndball, for å kunne gi bedre beskrivelser av skadesituasjonene og dermed iverksette tiltak som kan forebygge brudd. Det er også behov for studier som kan identifisere barn med økt risiko for bruddskader, sier Randsborg.

\section{Anne Forus}

anne.forus@hotmail.com

Tidsskriftet

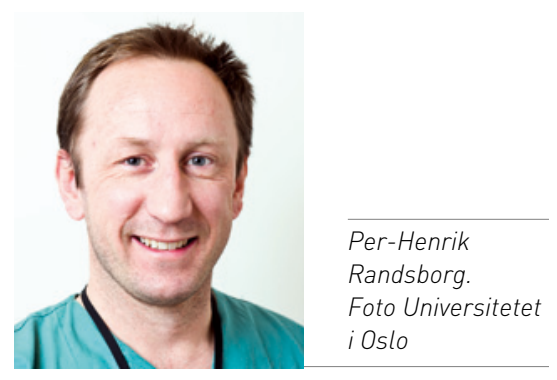

Disputas

Per-Henrik Randsborg disputerte for ph.d.graden ved Universitetet i Oslo 8.6. 2012.

Tittel på avhandlingen er Fractures in children: aspects on health service, epidemiology and risk factors. 